\title{
PENGARUH PENGGUNAAN LKS BERBASIS HOTS TERHADAP MOTIVASI DAN HASIL BELAJAR IPA SISWA SMP
}

\author{
Karsono \\ SMPN 1 Petungkriyono. J1. Raya Petungkriyono Kab. Pekalongan, Jawa Tengah, Indonesia \\ Korespondensi Penulis. E-mail: karsono_kenzie@yahoo.co.id \\ Received:10 January 2017; Revised:10 March 2017; Accepted: 10 April 2017
}

\begin{abstract}
Abstrak
Penelitian ini bertujuan untuk mendeskripsikan pengaruh penggunaan LKS berbasis HOTS terhadap motivasi dan hasil belajar IPA siswa Kelas VIII SMPN 1 Petungkriyono Kabupaten Pekalongan. Penelitian ini merupakan penelitian eksperimen semu dengan variabel terikat berupa motivasi dan hasil belajar IPA dan variabel bebasnya adalah penggunaan LKS berbasis HOTS. Desain penelitiannya yaitu desain kelompok kontrol nonekuivalen. Subjek penelitian sebanyak 53 siswa yang terbagi dalan dua kelas yaitu 25 kelompok eksperimen dan 28 siswa kelompok kontrol. Instrumen pengumpulan data yang dipergunakan berupa angket motivasi belajar dan tes hasil belajar IPA. Data motivasi dan hasil belajar dianalisis dengan menggunakan multivariat test (MANOVA) dan independent t-test dengan taraf signifikansi 5\% $(\alpha=0,05)$. Hasil uji multivariat pada Hoteling trace menunjukkan nilai signifikansi 0,000 . Hasil analisis perbedaan rata-rata motivasi belajar menghasilkan nilai 0,000 (2-tailed) sedangkan hasil belajar menghasilkan nilai 0,909 (2-tailed) dengan taraf signifikansi 5\%. Hasil ini menunjukkan bahwa penggunaan LKS berbasis HOTS berpengaruh positif dan signifikan terhadap motivasi belajar tetapi penggunaan LKS berbasis HOTS tidak berpengaruh positif dan signifikan terhadap hasil belajar IPA.
\end{abstract}

Kata Kunci: LKS berbasis HOTS, motivasi dan hasil belajar IPA

\section{THE EFFECT OF USING HOTS-BASED STUDENT WORKSHEET ON MOTIVATION AND LEARNING OUTCOME IN SCIENCE AMONG STUDENTS OF JUNIOR HIGH SCHOOL}

\begin{abstract}
This study aimed to describe the effect of using HOTS-based student worksheet on motivation and science learning outcomes of grade VIII students of SMPN 1 Petungkriyono Pekalongan. This study was a quasi-experimental research with the dependent variables were motivation and science learning outcomes and the independent variable was HOTS-based learning. Design of research was the design of the control group nonequivalen. The research subjects were 53 students which divided into two classes, namely 25 experimental group students and 28 control group students. The Data collection instruments used in the form of learning motivation questionnaire and science achievement test.The data of motivation and learning outcomes were analyzed using multivariate test (MANOVA) and independent $t$-test with significance level of $5 \%(\alpha=0.05)$. The results of multivariate analysis on Hoteling trace showed the significant value of 0.000 . The results of the analysis of the average difference in learning motivation produced a value of 0.000 (2-tailed) while for learning outcomes 0.909 (2-tailed) with significance level of 5\%. These results indicate that using HOTS-based student worksheet gave positive and significant impact on motivation to learn, but not positive and significant impact on science learning outcomes.
\end{abstract}

Keywords: HOTS-based student worksheet, motivation, science learning outcomes

How to Cite: Karsono, K. (2017). Pengaruh penggunaan LKS berbasis hots terhadap motivasi dan hasil belajar IPA siswa SMP. Jurnal Pendidikan Matematika dan Sains, 5(1). doi:http://dx.doi.org/10.21831/jpms.v5i1.13540

Permalink/DOI: DOI: http://dx.doi.org/10.21831/jpms.v5i1.13540 


\section{PENDAHULUAN}

Persaingan dalam era globalisasi memerlukan life skills yang memadai. Life skills diperlukan dalam menghadapi permasalahan sehingga ditemukan solusi pemecahannya. Permasalahan dalam kehidupan di era abad 21 ini begitu kompleks. Keterampilan pemecahan masalah dalam hidup berkaitan erat dengan keterampilan berpikir yaitu keterampilan berpikir tingkat tinggi (higher order thinking skills).

Keterampilan berpikir tingkat tinggi hendaknya ditanamkan kepada anak sejak dini. Kemampuan berpikir tingkat tinggi anak dapat diakomodasi melalui kurikulum dalam pendidikan dengan menerapkan pembelajaran yang bermakna. Pembelajaran yang mengutamakan pengembangan keterampilan berpikir siswa merupakan pembelajaran yang bermakna.

Praktik pembelajaran harus dapat memaksimalkan kerja otak dalam berpikir sehingga keterampilan berpikir terutama berpikir tingkat tinggi pada siswa dapat terakomodasi dengan baik. Pembelajaran harus dapat melibatkan keaktifan siswa dalam belajar. Konstruksi model pembelajaran maupun bahan ajar yang bermuara pada harapan itu penting untuk dilakukan, mengingat berhasil atau tidaknya proses pendididkan itu tolak ukurnya adalah siswa melalui proses evaluasi sehingga perlu upaya untuk merekonstruksi paradigma proses pendidikan, yaitu dari paradigma proses pengajaran ke paradigma proses pembelajaran yang mampu menciptakan proses pembelajaran yang interaktif, berpusat pada peserta didik, dan memiliki kemampuan berpikir tingkat tinggi..

Dimensi IPA pada hakikatnya berupa produk, proses, sikap ilmiah dan aplikasinya dalam kehidupan serta pengembangan dimensi kreativitas. Pembelajaran IPA diarahkan untuk mencari tahu dan berbuat sehingga dapat membuat siswa untuk memperoleh pemahaman yang lebih men-dalam tentang alam sekitar (Depdiknas, 2006b: 443). Pembelajaran IPA seharusnya dilaksanakan secara inkuiri untuk menumbuhkan kemapuan berpikir, bekerja dan bersikap ilmiah serta berko-munikasi sebagai salah satu aspek penting keca-kapan hidup (Depdiknas, 2006b: 443). Pembe-lajaran IPA bukan hanya untuk menguasai sejumlah pengetahuan sebagai produk, melainkan menekankan bagaimana siswa itu berproses dalam mendapatkan pengalaman sehingga siswa memi-liki kemampuan dalam mengaplikasikan ilmu dan memiliki sikap ilmiah dan terbiasa berpikir kritis dan kreatif serta dapat memecahkan bebagai permasalahan yang kompleks.

Motivasi merupakan bagian integral dalam pembelajaran. Siswa yang memiliki motivasi belajar yang tinggi biasanya akan mendapatkan hasil belajar yang tinggi demikian juga sebalik-nya siswa yang memiliki motivasi belajar yang rendah biasanya akan mendapatkan nilai yang rendah juga. Motivasi dipengaruhi oleh dua faktor yaitu faktor internal dan faktor eksternal dari individu atau siswa itu sendiri. Motivasi belajar seorang siswa tentu berbeda dengan siswa lain. Motivasi belajar juga dipengaruhi oleh sosial budaya masyarakat tempat tinggal siswa.

Pembelajaran merupakan proses sistemik yang melibatkan interaksi antara guru dengan siswa, siswa dengan siswa serta siswa dengan sumber belajar. Logikanya bahwa proses pembe-lajaran yang dijalankan dengan baik akan dapat menghasilkan motivasi dan hasil belajar yang tinggi pula. IPA sebagai salah satu cabang ilmu memiliki karakteristik tersendiri. Dimensi IPA berupa produk, proses, sikap dan aplikasi serta kreativitas membutuhkan cara tersendiri pula dalam pelaksanaan pembelajarannya.

IPA seharusnya tidak dibelajarkan sebagai produk saja tetapi harus dibelajarkan melalui pro-ses berpikir (way of thinking) sehingga keteram-pilan berpikir siswa terutama keterampilan ber-pikir tingkat tinggi dapat berkembang. Pembe-lajaran seperti ini memerlukan fasilitasi dari guru sehingga olah pikir atau minds on siswa dapat terwujud. Penyelidikan merupakan hal yang tidak bisa dilepaskan dari IPA karena IPA merupakan way of investigation. Pembelajaran yang dapat menfasilitasi olah tangan (hands on) dapat menjadi pembelajaran yang penuh makna. Hal ini disebabkan karena dengan melakukan investigasi siswa dapat memiliki pengalaman belajar yang tidak mudah dilupakan sehingga ketika meng-hadapi situasi yang berbeda dapat menyele-saikannya dengan tepat.

IPA merupakan pengetahuan yang pemerolehannya melalui olah pikir dan olah tangan atau minds on dan hands on. Fasilitas untuk dapat mewujudkan minds on dan hands on pada pembelajaran IPA di antaranya adalah dengan meyediakan bahan ajar yang dapat memenuhi kebutuhan tersebut. Bahan ajar salah satunya adalah lembar kegiatan siswa atau LKS. LKS merupakan lembaran-lembaran yang berisi tugas 
yang harus dikerjakan siswa. Penyusunan LKS secara menarik diharapkan dapat meningkatkan motivasi belajar, demikian juga tugas-tugas yang ada diharapkan dapat menjadi panduan bagi siswa dalam melakukan investigasi sehingga hands on dapat berkembang. Penyusunan LKS yang baik juga dapat mempengaruhi peningkatan motivasi belajar sehingga hasil belajar siswa menjadi tinggi.

Objek IPA meliputi makhluk hidup dari dapat dilihat dengan mata sampai yang tidak terlihat oleh mata beserta proses-proses kimia yang terjadi di dalamnya dan benda tak hidup yang ada di bumi dan seluruh jagad raya. Objek IPA ada yang dapat dilihat langsung oleh siswa juga ada yang tidak dapat dilihat karena berukuran yang terlalu kecil sebagai contohnya adalah bakteri. Konsep-konsep pada IPA juga banyak yang tidak dapat dijelaskan hanya dengan kata-kata saja melainkan memerlukan alat bantu dalam konseptualisasinya misalnya adalah kon-sep tentang atom maupun pembentukan ion.

Konseptualisasi objek IPA dapat dibantu dengan media. Pengetahuan tentang proses atau konsep yang tidak dapat dilihat dalam objek IPA dapat dikonseptualisasikan dengan media presen-tasi sehingga diharapkan dapat mengembangkan olah pikir siswa (hands on) sehingga hasil belajar sebagai muara pendidikan dapat meningkat.

Kegiatan pembelajaran yang melibatkan minds on dan hands on dalam praktiknya akan menumbuhkan keterampilan berpikir tingkat tinggi (higher order thinking skills). Higher order thinking skills merupakan keterampilan berpikir tingkat tinggi yang harus dimiliki siswa sehingga siswa dapat mempraktikan ilmunya dalam kehidupan.

Berdasarkan pengamatan di SMP Negeri 1 Petungkriyono ditemukan bahwa pola belajar dengan textbook sangat dominan, sementara pembelajaran dengan metode pemecahan masalah, inkuiry, discovery learning, belajar kelompok yang mengedepankan keterampilan berpikir tingkat tinggi hampir tidak digunakan. Pembelajaran IPA masih didominasi dengan pembelajaran yang menempatkan IPA sebagai produk saja karena pembelajaran masih menggunakan metode ceramah. Metode ceramah menyebabkan siswa kurang aktif dalam pembelajaran. Kekurangaktifan siswa sebagai dampak dari penggunaan metode ceramah dalam pembelajaran menyebabkan higher order thinking skills siswa rendah. Hal ini disebabkan karena keterampilan berpikir tingkat tinggi dalam pembelajaran tidak diakomodasi dengan baik.

Pembelajaran yang mengedepankan IPA sebagai produk dengan mengabaikan pembelajaran IPA sebagai proses berpikir ataupun berinvestigasi menyebabkan motivasi dan hasil belajar siswa rendah.

LKS yang dikemas dengan menarik diharapkan dapat meningkatkan motivasi belajar siswa. Selain itu, LKS yang didasari pada keterampilan berpikir tingkat tinggi diharapkan dapat meningkatkan keterampilan berpikir tingkat tinggi siswa. Higher order thinking skills sebagai salah satu kompetensi abad XXI merupakan keterampilan berpikir yang harus dimiliki anak di era globalisasi ini. Hasil penelitian Musfiqi \& Jailani (2014) menunjukkan bahwa bahan ajar yang berorientasi pada HOTS dapat meningkatkan karakter dan HOTS siswa. perangkat pembelajaran berorientasi HOTS juga efektif untuk meningkatkan persentase ketuntasan belajar klasikal siswa (Susanto \& Retnawati, 2016). Dengan demikian penggunaan LKS berbasis HOTS sebagai salah satu bahan ajar diharapkan dapat meningkatkan keterampilan berpikir tingkat tinggi sehingga hasil belajar siswa menjadi tinggi meningkat.

Berdasarkan uraian yang dikemukakan tersebut, maka tujuan dari penelitian ini adalah untuk mengetahui (1) pengaruh penggunaan LKS berbasis HOTS terhadap motivasi belajar, (2) pengaruh penggunaan LKS berbasis HOTS terhadap hasil belajar IPA siswa Kelas VIII SMPN 1 Petungkriyono Kabupaten Pekalongan.

\section{METODE}

Penelitian ini menggunakan pendekatan kuantitatif. Penelitian dilaksanakan pada tanggal 21 April sampai 31 Mei 214 di SMPN 1 Petungkriyono Kabupaten Pekalongan. Penelitian ini termasuk dalam penelitian quasi eksperimen. Penentuan kelompok eksperimen dan kelompok kontrol dilakukan secara acak, yaitu dari tiga kelas yang ada dipilih dua kelas secara random. Kelas eksperimen dalam pembelajarannya meng-gunakan LKS berbasis HOTS sedangkan kelom-pok kontrol pembelajarannya tanpa menggu-nakan LKS berbasis HOTS.

\section{Prosedur Penelitian}

\section{Pretest}

Pretes tidak dilakukan utuk variabel motivasi belajar karena diasumsikan motivasi awal siswa di SMPN 1 Petungkriyono adalah sama. 
Pretes dilakukan pada kemampuan awal siswa mengenai materi yang akan diberikan. Soal yang diberikan berupa tes pilihan ganda dengan empat opsi jawaban. Jawaban yang benar memperoleh skor satu dan jawaban yang salah memperoleh skor 0. Data ini digunakan untuk mendapatkan informasi mengenai normalitas dan homogenitas data subjek penelitian. Pretes tidak dilakukan pada motivasi belajar karena diasumsikan moti-vasi awal siswa adalah sama pada kedua kelompok.

\section{Perlakuan}

Perlakuan yang dimaksud di sini adalah perlakuan dalam pembelajaran. Kelas eksperimen pembelajarannya dilakukan dengan menggunakan media LKS berbasis HOTS. LKS berbasis HOTS merupakan LKS yang berbasis keterampilan berpikir kritis yang terdiri dari keterampilan dalam membedakan dan pengelom-pokkan dan klasifikasi, analisis, evaluasi dan membuat kesimpulan dari materi yang diberikan berupa atom, ion dan molekul dalam kehidupan.

\section{Posttest}

Postes dilakukan dengan memberikan soal pilihan ganda dengan empat opsi jawaban serta memberikan angket motivasi belajar yang dibuat sesuai dengan kisi-kisi instrumen penelitian.
Kelompok kontrol dalam pembelajarannya tidak menggunakan LKS berbasis HOTS.

Analisis data berupa ujicoba soal diolah menggunakan program iteman untuk mendapakan informaasi mengenai tingkat kesukaran dan daya beda serta reliabilitas butir soal pilihan ganda. Data pretes kemampuan awal siswa dan data postes diolah menggunakan program SPSS versi 16 for windows.

\section{HASIL DAN PEMBAHASAN}

Uji normalitas untuk data pretes kemampuan awal siswa pada kelas eksperimen didapatkan nilai 0,200 sedangkan pada kelas kontrol didapatkan nilai 0,151 . Hal ini menunjukkan bahwa data kedua kelompok berdistribusi normal untuk taraf signifikansi $5 \%$. Homogenitas data pada kedua kelompok diperoleh nilai signifikansi 0,351 yang berarti dapat dinyatakan pada taraf signifikansi $5 \%$ kedua kelompok homogen.

Tabel 1 berikut merupakan data motivasi dan hasil belajar kelas eksperimen dan kelas kontrol. Berdasarkan Tabel 1, ada perbedaan rerata skor motivasi antara kelas eksperimen dan kelas kontrol. Nilai rerata motivasi kelas eksperimen 1,60 dan kelas kontrol 0,83. Skor rerata motivasi kelas eksperimen dan kelas kontrol juga ditunjukkan oleh Gambar 1.

Tabel 1. Statistik Deskriptif Motivasi dan Hasil Belajar IPA Siswa

\begin{tabular}{llllllll}
\hline No & \multicolumn{1}{c}{ Variabel } & N & $\begin{array}{c}\text { Skor } \\
\text { Minimum }\end{array}$ & $\begin{array}{c}\text { Skor } \\
\text { Maksimum }\end{array}$ & Jumlah & Rerata & $\begin{array}{c}\text { Standar } \\
\text { Deviasi }\end{array}$ \\
\hline 1. & $\begin{array}{l}\text { Motivasi Belajar } \\
\text { (Kelas }\end{array}$ & 25 & 0,26 & 2,58 & 39,88 & 1,60 & 0,60 \\
2. & $\begin{array}{l}\text { Eksperimen) } \\
\text { Motivasi Belajar } \\
\text { (Kelas Kontrol) }\end{array}$ & 28 & 0,09 & 1,72 & 23,15 & 0,83 & 0,34 \\
3. & $\begin{array}{l}\text { Hasil Belajar } \\
\text { (Kelas }\end{array}$ & 25 & 16 & 33 & 638 & 25,52 & 4,45 \\
Eksperimen) & & & & & & \\
\hline
\end{tabular}




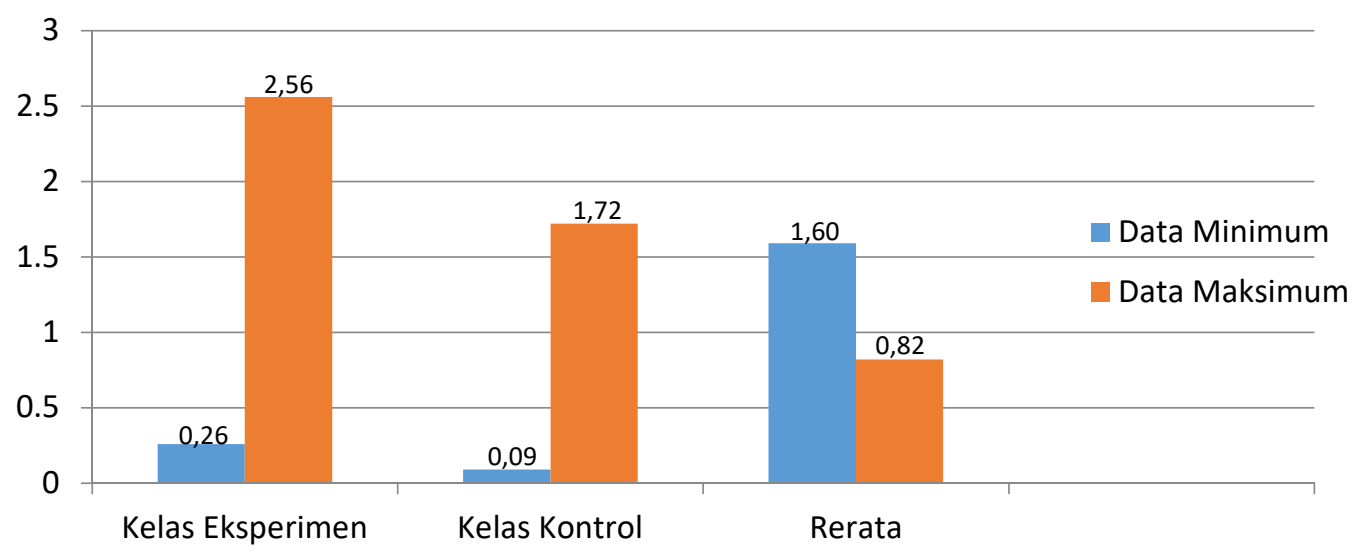

Gambar 1. Perbandingan Skor Motivasi Belajar Kelas Eksperimen dan Kontrol

Berdasarkan Tabel 1, ada perbedaan rerata skor hasil belajar antara kelas eksperimen dan kelas kontrol. Nilai rerata motivasi kelas eksperimen 25,52 dan kelas Kontrol 25,68. Skor rerata hasil belajar kelas eksperimen dan kelas kontrol ditunjukkan oleh Gambar 2.

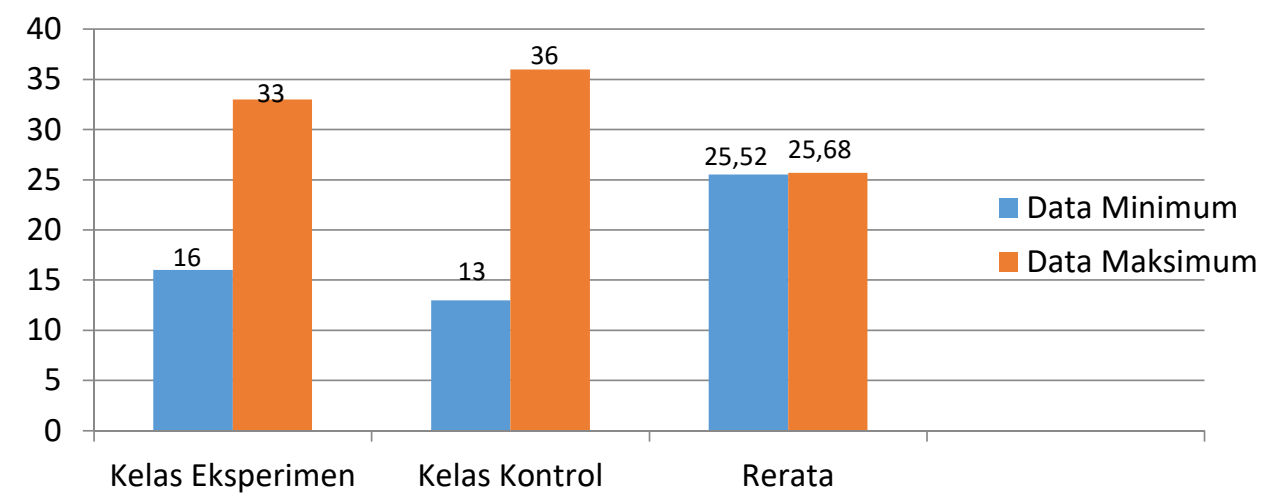

Gambar 2. Perbandingan Skor Hasil Belajar Kelas Eksperimen dan Kontrol

Uji Manova dilakukan untuk mengetahui pengaruh penggunaan LKS berbasis HOTS terhadap motivasi dan hasil belajar secara bersama-sama. Pengujian ini dapat dilakukan jika memenuhi syarat homogenitas matriks varian-kovarian. Tabel 2 menunjukkan hasil uji homo-genitas matriks varian-kovarian dua variabel dependen.

Tabel 2. Uji Homogenitas Matriks VarianKovarian

\begin{tabular}{ccc}
\hline No & $\begin{array}{c}\text { Box's test of Equality } \\
\text { Of Covariance Matrice }\end{array}$ & Nilai \\
\hline 1. & Box's M & 11,162 \\
2. & F & 3,562 \\
3. & df1 & 3 \\
4. & df2 & 8,304 \\
5. & Sig. & 0,014 \\
\hline
\end{tabular}

Berdasarkan Tabel 2, Nilai Box's M adalah 11,162 dengan signifikansi 0,014 . Nilai signifikansi ini lebih kecil dari 0,05 . Hal ini berarti matriks varian-kovarian dari variabel dependen adalah berbeda. Namun nilai F robust sehingga uji dapat dilanjutkan. lah:

Adapun hipotesis untuk uji Manova ada-

$\mathrm{H}_{0}:\left(\begin{array}{l}\mu_{11} \\ \mu_{12}\end{array}\right) \leq\left(\begin{array}{l}\mu_{21} \\ \mu_{22}\end{array}\right)$ : tidak ada pengaruh yang positif dan signifikan dari penggunaan LKS berbasis HOTS terhadap motivasi dan hasil belajar IPA siswa kelas VIII SMP N 1 Petungkriyono Kabupaten Pekalongan $\mathrm{H}_{\mathrm{a}}:\left(\begin{array}{l}\mu_{11} \\ \mu_{12}\end{array}\right)>\left(\begin{array}{l}\mu_{21} \\ \mu_{22}\end{array}\right)$ : ada pengaruh yang positif dan signifikan dari penggunaan LKS berbasis HOTS terhadap motivasi dan hasil belajar IPA siswa kelas VIII SMP N 1 Petungkriyono Kabupaten Pekalongan.

Pengambilan keputusan dan penarikan kesimpilan terhadap Uji Manova dengan kriteria Ho diterima apabila nilai signifikansi $>0,05$; sebaliknya jika nilai signifikansi $<0,05$ berarti Ho ditolak. Hasil analisis menggunakan SPSS 
16.0 ditunjukkan pada Tabel 3. Pada uji Uji Multivariat yang digunakan sebagai patokan adalah Uji Hotelling Trace karena variabel dependen yang digunakan hanya dua variabel.

Tabel 3. Uji Multivariat

\begin{tabular}{cc}
\hline Jenis Uji & Nilai Signifikansi \\
\hline Hotelling's Trace & 0,000 \\
\hline
\end{tabular}

Berdasarkan Tabel 4, dapat diketahui bahwa nilai signifikansi Uji Hotelling Trace adalah 0,000 dan lebih kecil dari 0,05. Maka pada taraf signifikansi $5 \%, \mathrm{H}_{0}$ ditolak dan dapat dinyatakan bahwa ada perbedaan antara kelas pada 2 variabel dependen dalam penelitian.

Tabel 4 memperlihatkan perbedaan interpretasi pada motivasi belajar dan Hasil belajar.

Tabel 4. Test of Between-Subject Effect

\begin{tabular}{ccccccc}
\hline Sumber & $\begin{array}{c}\text { Variabel } \\
\text { dependen }\end{array}$ & $\begin{array}{c}\text { Type III of Sum } \\
\text { Squares }\end{array}$ & df & $\begin{array}{c}\text { Mean } \\
\text { Square }\end{array}$ & F & Sig. \\
\hline Kelas & Motivasi Belajar & 7,799 & 1 & 7,799 & 33,00 & 0,000 \\
\hline & Hasil Belajar & 0,332 & 1 & 0,332 & 0,013 & 0,910 \\
\hline
\end{tabular}

Hasil Test Between-Subject Effect dari motivasi belajar diperoleh nilai $\mathrm{F}$ sebesar 33,00 dengan signifikansi 0,000 ( lebih kecil 0,05). Hal ini menunjukkan terdapat pengaruh yang positif dan signifikan dari penggunaan LKS berbasis HOTS terhadap motivasi belajar IPA pada kedua kelas pada taraf signifikansi $5 \%$. Variabel hasil belajar, didapatkan nilai $\mathrm{F}$ sebesar 0,013 dengan nilai signifikansi sebesar 0,910 (lebih besar dari 0,05), maka dapat dinyatakan bahwa tidak terdapat perbedaan hasil belajar IPA pada kedua kelas pada taraf signifikansi $5 \%$.

Uji selanjutnya dilakukan untuk mengetahui pengaruh penggunaan LKS berbasis HOTS terhadap motivasi dan hasil belajar antara kelas eksperimen yang dalam pembelajarannya meng- gunakan LKS berbasis HOTS dengan kelas kontrol yang pembelajarannya tanpa menggunakan LKS berbasis HOTS. Pengujian hipotesis menggunakan uji independent t-test. Hipotesis pertama berbunyi sebagai berikut.

Ho: $\mu_{11} \leq \mu_{21}$ : tidak ada pengaruh yang positif dan signifikan dari penggunaan LKS berbasis HOTS terhadap motivasi belajar IPA siswa kelas VIII SMPN 1 Petungkriyono Kabupaten Pekalongan

$\mathrm{H}_{\mathrm{a}}: \mu_{11}>{ }_{21}$ : ada pengaruh yang positif dan signifikan penggunaan LKS berbasis HOTS terhadap motivasi belajar IPA siswa Kelas VIII SMPN 1 Petungkriyono Kabupaten Pekalongan.

Hasil analisis menggunakan SPSS 16.0 for windows ditunjukkan oleh Tabel 5.

Tabel 5. Hasil Uji Independent t-test Motivasi dan Hasil Belajar IPA

\begin{tabular}{|c|c|c|c|c|c|c|}
\hline \multirow[b]{2}{*}{ No. } & \multirow[b]{2}{*}{ Variabel } & \multirow[b]{2}{*}{$\begin{array}{l}\text { Nilai } \\
\text { t-test }\end{array}$} & \multicolumn{2}{|c|}{ Rerata } & \multirow[b]{2}{*}{$\begin{array}{l}\text { Sig. }(2- \\
\text { tailed })\end{array}$} & \multirow[b]{2}{*}{ Keterangan } \\
\hline & & & $\begin{array}{c}\text { Kelas } \\
\text { Eksperimen }\end{array}$ & $\begin{array}{c}\text { Kelas } \\
\text { Kontrol }\end{array}$ & & \\
\hline 1 & Motivasi & 5,575 & 1,60 & 0,82 & 0,00 & Ho ditolak \\
\hline 2 & Hasil Belajar & $-0,113$ & 25,52 & 25,68 & 0,910 & Ho diterima \\
\hline
\end{tabular}

Berdasarkan analisis uji t pada Tabel 5, Ho ditolak sehingga Ha diterima. Jadi, disimpulkan bahwa ada pengaruh positif dan signifikan dari penggunaan LKS berbasis HOTS terhadap motivasi belajar IPA.

Pengujian hipotesis kedua menggunakan uji independent $t$-test. Hipotesis kedua berbunyi sebagai berikut.

$\mathrm{H}_{0}: \mu_{21} \leq \mu_{22}$ : tidak ada pengaruh yang positif dan signifikan dari penggunaan LKS berbasis HOTS terhadap hasil belajar IPA siswa ke-las VIII SMPN 1 Petungkriyono Kabupaten Pekalongan

$\mathrm{H}_{0}: \mu_{21}>\mu_{22}$ : ada pengaruh yang positif dan signifikan dari penggunaan LKS berbasis HOTS terhadap hasil belajar IPA siswa ke- las VIII SMPN 1 Petungkriyono Kabupaten

Pekalongan.

Adapun kriteria pengujian hipotesis yaitu Ho diterima jika sig.2-tailed $>0,05$; sebaliknya Ho ditolak jika sig.2-tailed $<0,05$. Berdasarkan analisis uji t yang dapat dilihat pada Tabel 5, nilai signifikansi untuk hasil belajar adalah 0,910 . Ini berarti Ho diterima. Hal ini berarti secara statistik tidak ada pengaruh penggunaan LKS berbasis HOTS terhadap hasil belajar IPA siswa kelas VIII SMPN 1 Petungkriyono Kabupaten Pekalongan.

Berdasarkan hasil analisis baik menggunakan uji $\mathrm{t}$ maupun uji Manova pada kedua variabel dependen didapatkan bahwa penggunaan LKS berbasis HOTS berpengaruh positif 
dan signifikan terhadap motivasi belajar IPA, tetapi penggunaan LKS berbasis HOTS tidak berpengaruh positif dan signifikan terhadap hasil belajar IPA.

\section{Pembahasan}

Penggunaan LKS berbasis HOTS yang berpengaruh terhadap motivasi belajar disebabkan karena beberapa faktor: (1) LKS berbasis HOTS merangsang kemauan siswa dalam belajar karena media yang ditawarkan selalu memun-culkan rasa penasaran siswa, (2) LKS berbasis HOTS mendorong rasa senang siswa karena menampilkan konsep yang tidak bisa diamati secara langsung dengan media lain dimana pembelajaran menggunakan tema yang sebenar-nya berhubungan langsung dengan kehidupan sehari-hari siswa, (3) LKS membantu siswa menemukan konsep IPA sehingga menjadi penghubung antara pengetahuan awal siswa yang disampaikan lewat powerpoint, (4) LKS yang digunakan merangsang kemauan siswa dalam belajar dikarenakan media yang ditawarkan bu-kan jawaban dari objek pengamatan, melainkan hanya petunjuk pelaksanaan saja, sehingga siswa menemukan sendiri apa yang dilakukan sesuai petunjuk LKS, (5) mendorong kemandirian siswa karena masing-masing siswa diberikan kesem-patan untuk melakukan reinforcement berupa keterampilan berpikir kritis.

Berkenaan dengan LKS yang digunakan dan dapat meningkatkan motivasi, Arsyad (2014: 40) menyebutkan beberapa kelebihan dari media cetak antaralain: (1) siswa dapat belajar dan maju sesuai dengan kecepatan masing-masing sehing-ga siswa diharapkan dapat menguasai materi pelajaran tersebut, (2) disamping dapat mengu-langi materi dalam media cetakan, siswa akan mengikuti urutan pikiran secara logis, (3) me-mungkinkan adanya perpaduan antara teks dan gambar yang menambah daya tarik, serta dapat memperlancar pemahaman informasi yang disaji-kan.

Penggunaan LKS yang tidak berpengaruh positif dan signifikan terhadap hasil belajar dapat ditinjau dari beberapa aspek: (1) perkembangan kognitif siswa, yaitu bahwa faktor yang paling dominan mempengaruhi adalah perkembangan kognitif peserta didik. Beberapa hal yang perlu diperhatikan adalah pengetahuan awal murid dan bagaimana animasi dibuat sebagai pemodelan. Kurangnya pengetahuan awal atas materi juga menyebabkan murid tidak tahu mana bagian penting dan harus diperhatikan guna memahami materi dan yang tidak. Kebanyakan siswa memperhatikan bagian yang tampak lebih menonjol secara perseptual. Penyampaian pesan informasi lewat media powerpoint dalam pembelajaran ini bersifat personal presentation dimana guru menayangkan animasi tersebut sampai dengan selesai sedangkan siswa hanya memperhatikan saja dari animasi pesan yang terdapat di dalamnya; (2) instrumen penelitian, yaitu bahwa penggunaan instrumen soal yang hanya berupa soal pilihan ganda dengan empat opsi jawaban menyebabkan siswa cenderung menyepelekan soal yang diujikan sehingga kemungkinan keseriusan siswa dalam mengikuti pembelajaran menjadi rendah. Hal ini menye-babkan hasil belajar kurang memuaskan; (3) media pembelajaran, yaitu layout dan animasi pemodelan yang digunakan masih terlalu sederhana. Hal ini menyebabkan daya tangkap siswa terhadap materi menjadi rendah dikarenakan proses pemberian model untuk keterampilan berpikir tingkat tinggi kurang dapat ditangkap dengan baik.Siswa yang pada kelas kontrol memiliki waktu yang lebih banyak untuk memahami materi yang diajarkan daripada siswa pada kelas eksperimen. Selain itu tersedianya sumber buku dapat menambah pemahaman mereka akan materi yang disampaikan; (4) proses penelitian, yaitu waktu penelitian yang relatif singkat yakni 4 x 40 berpengaruh terhadap hasil penelitian. Waktu yang singkat belum bisa untuk melihat sepenuhnya pengaruh treatment yang dilakukan terhadap hasil belajar siswa. Selain itu kondisi fisik merasa lelah karena pelajaran olahraga yang mereka ikuti sebelum pelajaran IPA dimulai di salah satu pertemuan per minggunya. Hal ini menyebakan siswa menjadi kurang fokus dalam pembelajaran; (5) sarana dan prasarana, yaitu kurangnya sarana yang ada menyebabkan hasil belajar kurang optimal. LCD projector yang belum terpasang di setiap kelas dan matinya instalasi listrik menyebabkan waktu pembelajaran menjadi tereduksi. Hal ini karena untuk pemasangan di kelas eksperimen memerlukan waktu yang cukup lama sehingga proses pembelajaran menjadi kurang maksimal; (6) sosial masyarakat, yaitu belajar juga dipengaruhi oleh kehidupan masyarakat tempat satuan pendidikan berada. Tingkat kesadaran masyarakat akan pendidikan juga masih rendah. Hal ini dibuktikan dengan masih dikirimnya guruguru SMPN 1 Petungkriyono ke Sekolah DasarSekolah Dasar untuk mengambil ijazah anak- 
anak yang baru lulus agar mau melanjutkan ke SMP.

\section{SIMPULAN}

Simpulan yang dapat diperoleh dari hasil penelitian ini adalah: (1) penggunaan LKS HOTS berpengaruh positif dan signifikan terhadap motivasi belajar IPA dan hasil belajar IPA siswa Kelas VIII SMPN 1 Petungkriyono Kabupaten Pekalongan secara simultan; (2) penggunaan LKS berbasis HOTS berpengaruh positif dan signifikan terhadap motivasi belajar IPA siswa Kelas VIII SMPN 1 Petungkriyono Kabupaten Pekalongan; dan (3) penggunaan LKS berbasis HOTS tidak berpengaruh positif dan signifikan terhadap hasil belajar IPA siswa Kelas VIII SMPN 1 Petungkriyono Kabupaten Pekalongan.

Saran yang dapat disampaikan dari hasil penelitian ini berdasarkan keterbatasan yang ada adalah: (1) layout LKS masih kurang sempurna sehingga disarankan perlu pengembangan LKS dengan layout yang lebih sempurna sehingga penggunaan media ini dapat efektif meningkatkan hasil belajar; (2) penggunaan media pendukung presentasi yang masih sederhana sehingga disarankan untuk mengembangkan media animasi pada tema atom, ion dan molekul dengan lebih baik.

\section{DAFTAR PUSTAKA}

Arsyad, A. (2014). Media pembelajaran. Jakarta: PT. Raja Grafindo Persada

Brookhart S. M. (2010). How to asses higher order thinking skills in your classroom. Alexandria: ASCD.

Chiappetta, E. L. \& Koballa, T. R. Jr. (2010). Science instruction in the middle and secondary schools $\left(7^{\text {th }}\right.$ ed.). New York: Allyn \& Bacon.

Darmodjo, H., \& Kaligis, J. R. E. (1993). Pendidikan IPA II. Jakarta: Dirjen Dikti.

Hamdani. (2011). Strategi belajar mengajar. Bandung: Penerbit CV. Pustaka Setia
Hedges, W. D. (1969). Testing and evaluation for the sciences. California: Wadsworth Publishing Company, Inc.

Ministry of Education Malaysia. (2002). Integrated curriculum for secondary schools: curriculum spesification science. Kuala lumpur: Ministry of Education Malaysia

Musfiqi, S., \& Jailani, J. (2014). Pengembangan bahan ajar matematika yang berorientasi pada karakter dan Higher Order Thinking Skills (HOTS). PYTHAGORAS: Jurnal Pendidikan Matematika, 9 (1), 45 - 59.

Moore, B., \& Stanley, T. (2010). Critical thinking and formative assesment. New York: Eye and Education, Inc.

Rusman, R., Kurniawan, D., \& Riyana, C. (2011). Pembelajaran berbasis teknologi informasi dan komunikasi. Jakarta: Rajawali Press

Sunyono. (2010). Pengembangan model lembar kerja siswa berorientasi keterampilan generik sains pada materi kesetimbangan kimia. Prosiding Seminar Nasional Kimia dan Pendidikan Kimia II. UNS: Solo,464469.

Susanto, E., \& Retnawati, H. (2016). Perangkat pembelajaran matematika bercirikan PBL untuk mengembangkan HOTS siswa SMA. Jurnal Riset Pendidikan Matematika, 3 (2), 189 - 197. doi:http://dx.doi.org/10.21831/jrpm.v3i2 .10631

\section{PROFIL SINGKAT}

Karsono. Lahir di Pekalongan, 18 Februari 1979. Gelar Sarjana (S1) diperoleh Tahun 2005 di Jurusan Pendidikan Biologi FMIPA Universitas Negeri Semarang. Pada Tahun 2012 melanjutkan studi di Program Studi Pendidikan Sains Program Pascasarjana Universitas Negeri Yogyakarta. Penulis menekuni pekerjaannya sebagai guru sejak tahun 2006 di SMPN 1 Petungkriyono Kab. Pekalongan, Jawa Tengah. 